\title{
Ecotourism Development in Indonesia: A Case Study in Kawah Putih, West Java
}

\author{
Dwinda Nafisah Nurinsiyah'1)2), Budhi Gunawan²), Teguh Husodo ${ }^{2)} \&$ Tomohiro Uchiyama ${ }^{3) *}$
}

\author{
インドネシアにおけるェコツーリズム開発の実態 \\ 一西ジャワのカワープティの事例分析一 \\ ヌリンシャー ドウィンダナフィサー1)2)・グナワン ブディ2)・フソド トゥグー 2$)$ ・ \\ 内山 智裕 3 *
}

エコッーリズムは過剰な開発等による環境破壊を 防ぐとともに，地元住民への職の提供など経済的な 価值もある一方, 環境破壊につながる可能性もあ る.インドネシア・西ジャワの Kawah Putih はエコ ツーリズムの対象として検証すべき地域である. 当 地域では国営会社 Perum Perhutani（以下：PP）が エコッーリズムに取り組んでいる. 本論では Kawah Putih を検討材料に, (1)PPに対する聞き取りから, 対象に打けるエコッーリズムのコンセプトを, (2)地
元住民に対する聞き取りから，エコッーリズムへの 関わりを，(3)来場者アンケートから，エコッーリズ ム活動への意識を，明らかにする．分析の結果，エ コッーリズムの負の側面が次の通り示される. (1) PP は地元住民との関わりが薄くなった. (2)PP は地元住 民と相談せずにッアーを行っており，地元住民には 収入減少に対する不満が存在する。（3来場者の多く は環境保護は大切だと考えるが，寄付等の意思のあ る人は少ない。

Key Words: ecotourism, environmental management, local economy, Indonesia

\section{Introduction}

Tourism has positive effects on conservation and employment, especially among locals. It raises consumer awareness of the protection of biodiversity and provides an economic incentive to preserve habitats that would otherwise be converted into unsustainable land (UNWTO, 2004; Kiss, 2004). Sustainable ecotourism development requires a healthy human society and ecosystem (Prescott-Allen, 2001; Seyhah and Usami, 2014).

Ecotourism development in Indonesia is promoted to conserve nature and support local welfare. For example, in Tanjung Puting National Park, Borneo, ecotourism activities not only provide economic incentives to manage the environment, but also decrease unemployment in local communities (Suarthana, 2011). On the contrary, ecotourism can negatively affect natural resources when poorly managed (Mieczkowski, 1995; Stabler, 1997; Li, 2003). Because ecotourism is engaged with the fragile environment, it runs the risk of ruining the biodiversity of ecosystems (Wood, 2002). Another challenge is pressure from tourists. As Boo (1993) states, most protected areas are not set up for tourism, thereby threatening their conservation.

Izawa (2010) argues that ecotourism in Indonesia

\footnotetext{
1) Graduate School of Bioresources, Mie University; 三重大学大学院生物資源学研究科

2) Graduate School of Ecology, Padjadjaran University; パジャジャラン大学大学院生態学研究科

3) Faculty of International Agriculture and Food Studies, Tokyo University of Agriculture; 東京農業大学国際食料情報学部

*E-mail: tu205722@nodai.ac.jp 
has been promoted in accordance with ecotourism principles or delivered on the expectation of providing alternative ways in which to use the country's diversity sustainably and economically in order to improve the living standards of Indonesian people.

To verify Izawa's argument with a concrete case of ecotourism in Indonesia, this study focuses on Kawah Putih (KP), which became a tourist attraction when Perum Perhutani (PP), a state-owned company responsible for the forests on Java Island, began to manage it in 1991. This study first describes ecotourism development in $\mathrm{KP}$ and then examines the participation of local communities in ecotourism. Next, it assesses tourists' awareness of conservation and willingness to participate in eco-activities and finally presents the challenges of $\mathrm{PP}$ as the ecotourism manager.

\section{Research methodology}

Qualitative methods were used to determine the value of ecotourism in $\mathrm{KP}$ and measure the roles of PP's staff and of the local communities. The planning and development managers and operational managers of PP's environmental services and other product departments, field officers in KP, and local entrepreneurs involved in KP ecotourism, totaling four $\mathrm{PP}$ and 10 operational staff as well as 24 local entrepreneurs (five of whom were not registered with PP), were interviewed between March 30 and April 2, 2014. The interview data were subsequently analyzed to examine the suitability of implementation with the ecotourism principles constructed by Wood (2002) and the Quebec Declaration (UNWTO et al., 2002). The four key indicators were as follows: (1) value of the contribution by operators (concession fees, donations, regulations); (2) economic alternatives for local people to reduce the exploitation of wildlife and resources (employed in tourism and conservation activities); (3) constituency building, which helps promote biodiversity conservation by tourists (conservation materials, tourist awareness); and (4) value received from tourists (fee, donations, volunteering).
In addition, this study used data obtained from a quantitative survey, which applied a non-probability sampling technique, to determine visitors' participation and willingness to participate in ecotourism activities. Questionnaires were collected from 40 weekday visitors and 86 weekend visitors upon the completion of their trips.

\section{Description of KP}

$\mathrm{KP}$ is one of two craters in Mount Patuha in West Java. It boasts a crater lake that changes color because of its high sulfur content and varying temperature. The high sulfur content also turns the surrounding rocks and sand white, which gives the tourist attraction its name (KP literally means "white crater").

The area surrounding KP is a habitat for 103 species of birds as well as other animals including panthers, leopards, and surilis. The area also features some protected plants.

A PP official informed us that around 250 visitors come to KP each weekday and 750 come each weekend. These numbers increase dramatically during the holiday season.

\section{Current tourism development in the KP area \\ (1) Tourist attractions}

KP boasts several tourist attractions in addition to its sulfur lake. First, Oxygen Ambassador, a conservation program, allows visitors to donate tree seedlings for forest conservation in $\mathrm{KP}$ and other PPmanaged areas. Visitors can also volunteer to plant infant trees during the rainy season. Second, Saung Kecapi is a small stage on which local musicians perform live music with Sundanese instruments. Third, KP's annual festival spreads an awareness of its natural and cultural heritage through photo contests, hiking tours, and cultural art performances.

(2) Trails

In addition, there are several sightseeing trails for tourists. The main trail runs straight to the sulfur lake and has a wheelchair-friendly observation area. There are also two mountain hiking trails for visitors desiring 
to see the sulfur lake from the top of Mt. Patuha. Most tourists, however, know the main trail only, as limited information is available. According to the author's observation, the hiking trails offer greater opportunities to learn about forest biodiversity than the main trail.

\section{(3) Tourism facilities}

Ontang-Anting is a shuttle car service provided by PP and local residents. It allows tourists to park in a commercial area (about $5 \mathrm{~km}$ away) and take shuttle cars to the main site.

Additionally, there are information centers at the entrance and at the main site of $\mathrm{KP}$; the former provides information on travel packages and group tours, while the latter provides health information and a profile of KP. A board at the main site also describes the history, flora, and fauna of KP. However, this information is not accessible to most foreign tourists as it is written only in Indonesian.

\section{(4) Tourist regulations}

In general, collected entrance fees provide dearly needed funds for natural area protection and management (Sherman and Dixon, 1991). Therefore, PP dedicates 20-30\% of its revenue to such endeavors. Table 1 shows the entrance fees paid by $\mathrm{KP}$ visitors. Further, an environmental service fee is charged to each tourist car entering the main site. This fee aims to encourage tourists to use public transportation (i.e., the shuttle cars) and thereby reduce traffic pollution.

Table 1. Entrance Fees Paid by KP Visitors (IDR)

\begin{tabular}{c|c|c|c|c}
\hline \hline \multirow{2}{*}{ Unit } & \multicolumn{2}{|c|}{ Domestic } & \multicolumn{2}{c}{ Foreign } \\
\cline { 2 - 5 } & $\begin{array}{c}\text { Week- } \\
\text { days }\end{array}$ & $\begin{array}{c}\text { Week- } \\
\text { end }\end{array}$ & $\begin{array}{c}\text { Week- } \\
\text { days }\end{array}$ & $\begin{array}{c}\text { Week- } \\
\text { end }\end{array}$ \\
\hline Adult & 8,000 & 12,000 & 22,500 & 30,000 \\
\hline $\begin{array}{c}\text { Child under 10 } \\
\text { years }\end{array}$ & 11,000 & 15,000 & 30,000 & 40,000 \\
\hline $\begin{array}{c}\text { Environment } \\
\text { charge }\end{array}$ & \multicolumn{4}{c}{$150,000 /$ car } \\
\hline Ontang-Anting & \multicolumn{4}{c}{13,000 (round trip) } \\
\hline
\end{tabular}

Source: Perum Perhutani (2014).

Notes: $1 \mathrm{JPY}=120$ IDR.

\section{(5) Local community participation}

Among the 16 PP staffs in the field office, only one was a local resident (the supervisor of the Environment Division). Of the 10 operational staff interviewed (including custodians, guides, and ticket vendors), only four were local residents. This fact shows that ecotourism in KP has provided few employment opportunities for locals.

The broader participation of locals can be seen in local business activities. As shown in Table 2, 88\% of entrepreneurs in KP are local citizens whose businesses are their main source of employment. Furthermore, we found that the local entrepreneurs shared with colleague part of business profit. This finding concurs with Stronza et al. (2008), who state that ecotourism activities generate not only economic benefits, but also non-economic ones including new skills, abilities, and broader experiences.

(6) New regulations in the local community

When KP was opened to the public in 1991, locals were allowed to build small shops in the area surrounding the crater. According to the current duty officer, PP strived to reduce pollution such as trash (e.g., by providing a trash bin every $25 \mathrm{~m}$ ); however, tourist waste, especially food waste, remained. Ceballos-Lascurain (1996) states that, in such situations, management zones (e.g., restricted zones)

Table 2. Local Entrepreneurs Interviewed

\begin{tabular}{c|c|c|c}
\hline \hline $\begin{array}{c}\text { Type of } \\
\text { Business }\end{array}$ & Number & $\begin{array}{c}\text { Ave. Income } \\
\text { (IDR) }\end{array}$ & $\begin{array}{c}\text { Profit Sharing } \\
\text { (IDR, \%) }\end{array}$ \\
\hline Shuttle Car & 2 & $1,500,000$ & $3,500 /$ passenger \\
\hline Food & 5 & $3,500,000$ & $50,000 /$ month \\
\hline $\begin{array}{c}\text { Strawberry } \\
\text { Seller }\end{array}$ & 3 & $2,000,000$ & $20,000 /$ month \\
\hline Souvenir & 1 & $1,000,000$ & $50,000 /$ month \\
\hline Toilet & 3 & $1,066,667$ & $30 \%$ \\
\hline Parking & 3 & $1,133,333$ & $30-50 \%$ \\
\hline Hotelier & 2 & $8,500,000$ & - \\
\hline Guide & 1 & $2,000,000$ & NA \\
\hline Others & 4 & 883,333 & - \\
\hline
\end{tabular}

Source: Authors' survey.

Notes: $1 \mathrm{JPY}=120$ IDR. 
should be established based on the natural and/or cultural values and fragility of a protected area as well as the carrying capacities of the species within it. Consequently, in 2010, management zones were introduced to relocate local shops to a commercial area 5 km away.

Relocating the local shops caused conflict between PP and locals. To deal with this, the two parties negotiated new regulations to support local economic activities. PP bought new stalls for local businesses under the expectation that visitors would park in the commercial area and spend more time shopping there before using the provided shuttles to the crater.

\section{Perception of ecotourism development in KP}

\section{(1) PP}

The officers in the main PP office and field officers in KP had different conceptions of ecotourism. According to the interviews, the managers in the main office understood that the purpose of ecotourism was not only to conserve the environment but also to improve the welfare of local residents. Supervisors in the site office, on the contrary, answered that ecotourism was merely tourism based around nature, while operational staff were unsure of its meaning. These different perceptions could stem from the ambiguous meaning of the Indonesian word for ecotourism. The words eko-tour (ecotour), ekowisata (ecotourism), and wisata alam (nature tourism) are used interchangeably to indicate ecotourism (Izawa, 2010). This ambiguity is particularly troublesome as Indonesia's nature tourism industry neither shows concern for the impact that tourism could have on local societies nor establishes a goal for sustainability.

However, although field officers did not fully understand the definition of ecotourism because of the ambiguity of ecotourism in Indonesian, the activities and endeavors in KP were appropriately implemented to embody managers' ideals; these considered not only conservation but also collaboration with locals under the manager's direction.

\section{(2) Local community}

Many local entrepreneurs, especially food and accessories vendors, complained that their income had decreased after relocation to the commercial area. While they realized the importance of the conservation of the main site, they were frustrated that few tourists visited their shops. Moreover, food vendors were upset when PP began to provide its own catering service.

Most respondents indicated that PP used to involve them in developing the programs and regulations. In negotiations, the local community had the right to express their opinions. Many respondents complained, however, that after the transfer of the shops, PP arranged few meetings and its purpose became only to promote its own programs. Therefore, local entrepreneurs are no longer the decision makers in KP ecotourism activities. PP must improve its communication with locals to maximize the environmental and economic benefits.

\section{(3) Tourists}

An essential element of ecotourism is the education of tourists on the importance of conservation (Gossling, 1999; Wood, 2002). Ecotourists must abide by local regulations and avoid damaging the natural environment (Chiu et al., 2014). Half of the interviewed KP tourists (50\% of weekday and $55 \%$ of weekend respondents) thought that the information provided by PP was effective at raising knowledge about the environmental conditions of the area. Respondents indicated that trash bins were well provided, information on the history, flora, and fauna of KP were presented on information boards, and announcements from the information center gave them health advice regarding the hazard of the area's sulfur deposits. However, the information was provided only in Indonesian. Therefore, if PP desires to attract international tourists, it should accommodate other languages.

For example, the history of Netherland Cave, a historical sulfur mining site, was not clearly explained. Although a sign communicating its name was hung at 
the front of the cave, it provided no additional information. To enhance visitors' knowledge, more information must be given.

As shown in Fig. 1, "not littering" was the activity that most respondents supported to protect the environment, followed by the usage of the OntangAnting shuttle. PP's efforts to raise tourists' awareness contribute to the environmental management of KP. However, the use of OntangAnting could be improved. Numerous respondents indicated that they had to wait for a long time for the shuttle service. Therefore, they chose to pay the environmental service fee to drive their own vehicle.

Although many tourists agreed that conservation is important for the biodiversity of KP (68\% of weekday and $78 \%$ of weekend respondents), few were willing to

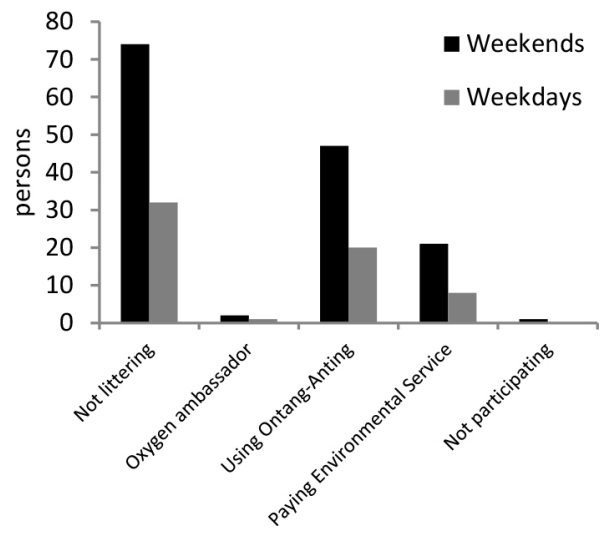

Fig. 1 Tourist Participation in Environmental Management Activities

Source: Authors' Survey. donate $(10,000-500,000$ IDR) or volunteer for conservation activities (Table 3). Some tourists said that the entrance fee was sufficient to cover this. Since the donations received from tourists can be used to conserve biodiversity and maintain protected forests, future ecotourism projects should focus on environmental education to encourage visitors to act in an environmentally conscious manner (UNWTO, 2004; Chiu et al., 2014).

\section{Conclusion}

As a developing industry in Indonesia, ecotourism is expected to serve as a suitable tool for environmental management while also benefiting both site operators and local communities. In KP, PP is not only protecting natural resources but also involving local communities. Through such community cooperation, tourism can provide an alternative income source to locals while avoiding unsustainable land utilization. However, PP faces some challenges in implementing the concept of ecotourism, such as the diversity of PP officers' ecotourism definitions, local communities' dissatisfaction with management, and high rate of unwillingness among tourists to support ecotourism activities after their visit. It should be noted, however, that PP must improve its communication with local vendors to avoid wasting its conservation efforts. Additionally, PP must improve its environmental education to raise tourists' awareness.

This study has elucidated challenges facing the ecotourism in KP managed by $\mathrm{PP}$, and provided recommendations to address them. Despite such

Table 3. Tourist Willingness to Participate by Gender

\begin{tabular}{|c|c|c|c|c|c|c|}
\hline \multirow{2}{*}{ Unit: \% } & \multicolumn{3}{|c|}{ Weekdays } & \multicolumn{3}{|c|}{ Weekends } \\
\hline & Man & Woman & Total & Man & Woman & Total \\
\hline Donation & 22.7 & 8.3 & 15.5 & 10.3 & 8.6 & 9.5 \\
\hline Volunteering & 13.6 & 33.3 & 23.5 & 33.3 & 25.7 & 29.5 \\
\hline Donation and Volunteering & - & 8.3 & 8.3 & 7.7 & 2.9 & 5.3 \\
\hline Not participate & 59.1 & 41.7 & 50.4 & 43.6 & 48.6 & 46.1 \\
\hline NA & 4.5 & 8.3 & 6.4 & 5.1 & 14.3 & 9.7 \\
\hline
\end{tabular}

Source: Authors' Survey. 
challenges, ecotourism can serve as a model of sustainable tourism development to provide Indonesian tourism models that have not only economic benefits, but also social and ecological benefits.

\section{Acknowledgements}

We would like to express our gratitude to the Ministry of Education in Indonesia and PP's support of our research into KP.

\section{References}

Boo, E. (1993) Ecotourism: Planning for Protected Areas. In: K. Lindberg and H. Donald (eds.) Ecotourism, A Guide For Planners and Managers. North Bennington, Vermont: The Ecotourism Society, 15-31.

Ceballos-Lascurain, H. (1996) Tourism, ecotourism, and protected areas. Gland, Switzerland: IUCN.

Chiu, Y. T. H., Lee W. I, and Chen T. H. (2014) Environmentally responsible behavior in ecotourism: Antecedents and implications. Tourism Management, 40, 321-329.

Gossling, S. (1999) Ecotourism: A means to safeguard biodiversity and ecosystem functions? Ecological Economics, 29, 303-320.

Izawa, T. (2010) Ecotourism in Bali. Journal of Ritsumeikan Social Sciences and Humanities, 2, 73-103.

Kiss, A. (2004) Is community-based ecotourism a good use of biodiversity conservation funds? Trends in Ecology and Evolution, 19, 232-237.

Li, W. (2004) Environmental management indicators for ecotourism in China's nature reserves: A case study in Tianmushan nature reserve in tourism management. Tourism
Management, 25, 559-564.

Mieczkowski, Z. (1995) Environmental Issue of Tourism and Recreation. Laham: University Press of America.

Prescott-Allen, R. (2001) The Wellbeing of Nations: A Country-byCountry Index of Quality of Life and the Environment. Washington, DC: Island Press.

Seyhah, V. and Usami, K. (2014) The sustainability of ecotourism in Cambodia: A case of Koh Phdao and Sampin villages. Journal of Rural Problem, 50, 173-178.

Sherman, P. and Dixon, J. A. (1991) The economics of nature tourism: Determining if it pays. In: T. Whelan (ed.) Nature Tourism: Managing for Environment. Washington DC: Island Press, 89-131.

Stabler, M. J. (1997) Tourism and Sustainability: Principles to Practice. New York: CAB International.

Stronza, A. and Gordilla, J. (2008) Community views of ecotourism. Annals of Tourism Research, 35, 448-468.

Suarthana, I. K. P. (2011) Ekowisata meningkatkan sosial ekonomi masyarakat (Ecotourism Improving Economic Community). Jurnal Ilmiah Manajemen dan Akuntansi, 16, Bali: STIE Triatma Mulya, 16(2), 24-33.

United Nations World Tourism Organization (UNWTO) (2004) Indicators of Sustainable Development for Tourism Destination: A Guide Book. Madrid: World Tourism Organization.

United Nations World Tourism Organization (UNWTO) and United Nations Environment Program (UNEP) (2002) Quebec declaration of ecotourism. (http://www.gdrc.org/uem/eco-tour/ quebec-declaration.pdf) [Accessed March 2, 2014].

Wood, M. E. (2002) Ecotourism: Principles, Practices, and Policies for Sustainability. Paris: UNEP Division of Technology, Industry and Economics. 